\title{
Analysis of Maklon Service Raw Material Control Using EOQ (Economic Order Quality) Method Based on Big Logistic Data to Support Industry 4.0
}

\author{
$1^{\text {st }}$ Dina Eka Shofiana ${ }^{1}, 2^{\text {nd }}$ Moh. Imsin ${ }^{2}$ \\ \{dinaekashofiana@fia.unipdu.ac.id/mohimsin@fia.unipdu.ac.id² ${ }^{2}$,
}

Fakultas Bisnis dan Bahasa Universitas Pesantren Tinggi Darul ‘Ulum (Unipdu)Jombang ${ }^{1,2}$

\begin{abstract}
This study aims to determine the control of raw materials for maklon services using the EOQ (Economic Order Quality) method based on big data logistics at CV. Surya Kencana Food. Raw materials have the potential difference in the arrival (in Going), the use of raw materials on the production services JasaMaklon. Because in this Jasa maklon industry Raw material is the responsibility of Vendor which Jasa maklon does not charge Raw material. So it is important that the control of raw materials for the maklon service is done to correction each other, the raw materials used in the shipping services are sent from the vendor, the recipient does not know the type of raw materials to be used, because it is required big data in the classification of Raw Materials there is no mistake in distributing raw materials in Operational Production. This research uses descriptive qualitative approach.The results of this study indicate that using EOQ (Economic Order Quality) method on raw material maklon based on big data by using data base more efficient than conventional method or without using data, this is proved by the level of controlling of raw material of maklon service on the arrival of raw materials, usage and stock position position can be run and seen the accuracy of data from big data Logistics.
\end{abstract}

Keywords: Economic Order Quality (EOQ), Big Data, Logistic.

\section{Introduction}

A business that is carried out commercially is always oriented to obtain maximum benefits or benefits. The efforts in this direction only allow it to be realized by directing and utilizing all the potential or resources (resources) that are owned to create and add to the utility (utility) of goods and services. To regulate these activities, decisions need to be made relating to efforts to achieve the objectives so that the goods and services produced are in accordance with what is planned. To achieve this plan, efficiency in all fields is needed.

One method that is quite efficient in managing raw material control is the EOQ method (Economic Order Quality). EOQ (Economic Order Quality) is an inventory control technique that minimizes the total cost of ordering and storing. (Heizer, J.d 2015: 561). EOQ Method (Economic Order Quality) strives to achieve the minimum inventory level, low cost and better quality. EOQ planning method (Economic Order Quality) in a company will be able to minimize the occurrence of stock shortages (out of stock) so as not to interfere with the production process in the company because there is efficiency in the supply of raw materials in the company concerned. In addition, with the application of the EOQ method (Economic 
Order Quality) the company will be able to reduce storage costs, save space, both for warehouse space and work space, resolve problems that arise from the large amount of inventory that piles up so as to reduce the risk that can arise.

CV. Surya Kencana Food is a maklon service company where all raw materials from the vendor realize that competition is increasingly competitive. Therefore, the right strategy is needed to deal with this competition. One strategy used by a company to win in competition is to reduce the cost to a minimum, manage the data base in big data so that the logistic inventory turn over can be controlled. Because in meeting the demands of its customers, companies need a large amount of raw material inventory. For this reason, it is necessary to plan a data base for big data inventory that is issued as efficiently as possible and does not become a problem that can drain large costs. CV. Surya Kencana Food has a problem in the method of recording in a database the raw material inventory, namely the receipt of raw materials that sometimes lack, so that the production process is disrupted due to the absence of raw materials to be processed, distribution of raw materials and supplies of existing raw materials.

The company requires a method to control the supply of raw materials and determine the availability of raw materials in the right quantity and time. For that the authors are interested in lifting the method of Economic Order Quantity (EOQ), where this method can minimize errors in inventory data, and existing bafer stock and cost control. Based on the background above, the authors are interested in conducting research with the title "Analysis of Raw Material Control of maklon services using the EOQ Method (Economic Order Quality) based on Big Data Logistics on CV. Surya Kencana Food”

\section{Theoretical Basis}

Production in a company is an activity that is quite important even in various talks. It can be said that production is the kitchen of the company. If the production activities in a company will come to a standstill, the activities in the company will also stop. Because also if there are various kinds of obstacles that result in the stagnation of production activities in a company. Then activities within the company will also be disrupted. Understanding of management itself according to Assauri (2004: 12) activities or efforts made to achieve the goal by using or coordinating the activities of others. While production according to Assauri (2004: 11) is an activity that transforms input (input) into a result of output (output). Production Management According to Assauri (2004: 12) is an activity to regulate and coordinate the use of resources in the form of Human Resources, Resource Tools and Fund Resources as well as materials, effectively and efficiently to create and add to the utility of goods and services.

\subsection{Understanding EOQ (Economic Order Quality).}

According to Heizer, Jd (2015: 561) EOQ (Economic Order Quality) is an inventory control technique that minimizes the total cost of ordering and storage. According to Mannulang (2005: 70) EOQ (Economic Order Quality) is a way to obtain a way to obtain a number of goods with minimum costs and supervision of order costs and Carrying costs.

Then according to Pardede (2005: 422) states that EOQ (Economic Order Quality) shows a number of items that must be ordered for each order so that the overall preparation costs become as small as possible. 


\subsection{Determining EOQ (Economic Order Quality)}

Determining inventory orders is by determining how much inventory the company needs in carrying out its activities. For this reason, an EOQ method (Economic Order Quantity) is needed in order to determine the economical quantity of inventory.

EOQ calculations according to Heizer, J.d (2015: 563), namely:

$\mathrm{EOQ}=\sqrt{ }(2 \mathrm{DS} / \mathrm{H})$

Information:

$\mathrm{EOQ}=$ The optimum number of units per order

$\mathrm{S}=$ Order cost for each order

$\mathrm{D}=$ Annual request in the unit

$\mathrm{H}=$ Storage cost per unit per year

In addition to the EOQ formula (Economic Order Quality), there are several formulas to support the calculation of inventory costs, including:

Available average inventory $=Q^{*} 2$

Estimated order inventory $=$ D. $Q^{*}$

Annual booking fee $=$ D. S. Q ${ }^{*}$

Annual storage fee $=Q^{*}$. H. 2

Total price per unit $=$ Price per unit $\times$ Order cost

Total annual costs $=$ Installation costs (orders) + Storage costs.

Safety Stock.

According to Rangkuti (2007: 10) safety stock is an additional inventory held to protect or maintain the possibility of a stock out.

Safety Stock Formula:

$\mathrm{Ss}=\mathrm{Z} \times \mathrm{S}$

Information:

Ss $=$ Safety stock or safety supplies

$\mathrm{Z}=$ Factor which is the amount of deviation of trust in service or safety factor whose amount is determined by the level of service level

$\mathrm{S}=$ Standard deviation of demand during the order grace period or standard deviation of demand over the lead time.

To find the standard deviation the formula is as follows:

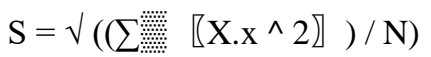

Information :

$\mathrm{S}=$ Standard devision.

$\mathrm{x}=$ Use of real raw materials.

$\sum=$ Average use of raw materials.

$\mathrm{N}=$ Amount of data. 


\section{Reorder Point}

According to Heizer, J.d (2015: 567) Reorder Point is the level of inventory (point) where to replenish inventory. Whereas according to Assauri (2016: 232) the assumption of Reorder Point is:

That a company will place an order, if its inventory level for a certain item has reached zero.

The company will receive the item it ordered immediately or immediately.

Description: $\mathrm{Q} *$ is the optimum order quantity and the waiting time represents the time between order placement and order receipt.

The formula for determining reorder points:

$\mathrm{ROP}=(\mathrm{d} \times \mathrm{L})+\mathrm{SS}$

Description:

$\mathrm{d}=$ Request per day

$\mathrm{L}=$ Time to wait for new orders in the day

This ROP equation assumes that the demand during the waiting time and the waiting time itself is constant. Requests per day (d) are calculated by dividing the annual demand (D) by the number of working days in a year:

$$
\text { Request per day }(\mathrm{D})=\frac{\mathrm{D}}{\text { Number of working days in one year. }}
$$

Big data is a control database

Big Data described by inspiration in article writing is a general term for all sets of data in a very large and complex amount that makes it difficult to handle or process if only using ordinary database management or traditional data processing applications. The most important thing about Big Data is not just the technical ability to process data but the benefits that can be realized by the company by using Big Data Analytics. The terminology of Big Data is believed to come from web search companies that process data with a very large and unstructured distribution. Big Data Example Big Data Data can be in the form of data up to petabytes (1,024 terabytes) or exabytes (1,024 petabytes), such as billions to trillions of someone's personal records, all of which come from different sources such as web, sales, customer service, social media, mobile data and so on.

Data analysis can be carried out descriptively through the description of past business situations to obtain trend trends and exceptions, predictive conducting real-time analysis and establishing historical data as predictions of the front while prespective measures prediction analysis to inform and suggest actions that function to take advantage or avoid certain results . 


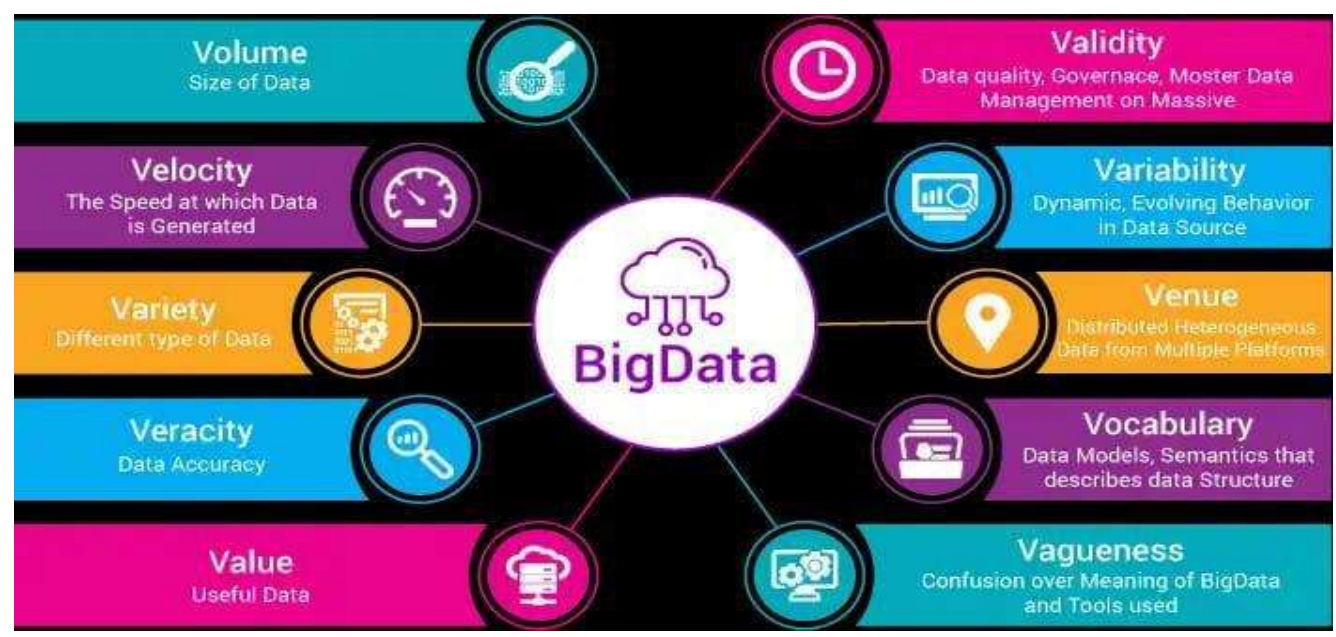

Big data is a solution to control the inventory of raw materials with the data obtained is the raw material data that is in stock maklon services by using the material trase code so as not to make mistakes made by Incoming QC before it is included in the formulation of material use which then goes into the production process. The data needed is raw material data, item data according to the code given by the vendor, raw material data from the supplier directly to the production usage data, so that the vendor can see the turnover of raw materials with big data.

\section{Research Methods}

According to Sugiyono (2015: 307) qualitative methods are research methods that are based on positivism / enterpretif philosophy, used to examine natural object conditions, (as opposed to experiments) where researchers are key instruments, data collection techniques are triangulated (combined), data analysis is inductive / qualitative, and the results of qualitative research emphasize the meaning rather than generalization. The design of this study is a descriptive study in which this study attempts to analyze the control of Raw Materials using the Big Data-based EOQ method at CV Surya Kencana Food, to explore in-depth data

The research subjects at this stage are the Heads of Warehouse / Logistics CV. Surya Kencana Food that manages Turn over Logistics with raw data in the form of road documents from the vendor and data Proof of receipt of raw materials by Formuli and Production Section at CV. Surya Kencana Food Jombang. After that, at the next stage, analyzing the raw data that has been entered with the EOQ method based on Big data, the point is to see the accuracy of the data made reference in the preparation of inventory stocks with accountable records Data collection can be done in various settings, various sources, and various way. When viewed from the settings, data can be collected from natural settings. When viewed from the data source, the data collection can use primary sources and secondary sources. Primary sources are data sources that directly provide data to data collectors and secondary data sources are sources that do not directly provide data to data collectors, for example through other people or documents . Various data collection techniques are shown in the following figure 3.1. 
Based on the picture, it can be seen that in general there are four types of data collection techniques, namely observation, interview, and combination / triangulation.

Data analysis in this study is descriptive analysis with a qualitative approach. According to Miles and Hubermen in Sugiyono (2016: 246), suggesting that activities in qualitative data analysis are carried out continuously until complete, so that the data is saturated. Activities in data analysis, namely data reduction, data display, and conclusion drawing / verification.

\section{Urgency (Principles) Research}

The results of the study provide input to be able to take steps and decisions to make preparations and improvements for the progress of the company and provide a good picture and hope for the company in managing raw material management due to raw materials. Through this research, it is expected that the author will deepen his knowledge in the field of operational management, especially the problem of controlling raw material inventory from big data, can provide recommendations for control of both the management and the employer vendors. in the field of operational management regarding the control of raw materials.

\section{Expected Findings And Innovations}

1. As a vehicle for building communication between Islamic boarding schools, the academic community and the small and medium entrepreneurs in the field of maklon services within the framework of mutually beneficial development and assistance.

2. To build business communication that has a continuous content of research and community service, in the framework of mutual cooperation (MOU) for the long term.

3. To bridge in building market communication through Islamic boarding schools and higher education networks within the framework of research and community service.

\section{References}

[1]. Arikunto, S. (2005). Manajemen Penelitian . Jakarta: Rineka Cipta.

[2]. Assauri, S. (2004). Manajemen Operasi Dan Produksi . Jakarta: Pt Jaya Grafindo Persada.

[3]. Baroto, T. (2006). Perencanaan Dan Pengendalian Produksi. Jakarta: Ghalia Indonesia.

[4]. Daryanto, S. (2007). Analisis Pengendalian Bahan Baku Terhadap Efesiensi Biaya Pada Pt.Menara Cipta Metalindo. Jurnal Administrasi Kantor Vol 3 No 2 Agustus 2015 , 9.

[5]. Daud, M. N. (2017). Analisis Pengendalian Persediaan Bahan Baku Produksi Roti Wilton Kualasimpang. Jurnal Samudra Ekonomi Dan Bisnis, Vol.8, No.2 .

[6]. Fajrin, E. H. (2016). Analisis Pengendalian Persediaan Bahan Baku Dengan Menggunakan Metode Economic Order Quality (Eoq) Pada Perusahaan Roti Bonansa. Managemen Analisi Joural , 1-10.

[7]. Handoko, H. T. (2011). Dasar-Dasar Manajemen Produksi Dan Operasi, Edisi 1. Yogyakarta: Bpfe Fakultas Ekonomi Ugm.

[8]. Heizer, J. D. (2015). Manajemen Operasi:Keberlangsungan Dan Rantai Pasokan. Edisi 11. Jakarta: Salemba Empat.

[9]. Kuncoro, M. (2011). Metode Penelitian . Jakarta : Pt.Erlangga.

[10]. Manullang, M. (2005). Dasar-Dasar Manajemen . Yogyakarta: Gajah Mada University.

[11]. Mulyadi. (2014). Akuntansi Biaya Edisi Lima . Yogyakarta: Upp Stim Ykpn . 
[12]. Maizawati (2017). Siab Online Sebagai Solusi Internet Of Things Transportasi Logistic Ejurnal Manejemen Indonesia, 39-48.

[13]. Natalia, F. (2017). Analisis Pengendalian Persediaan Bahan Baku Dengan Menggunakan Metode Eoq (Economic Order Quality) Pada Primed Konvekdi Di Samarinda. Ejurnal Administrasi Bisnis , 1065-1075.

[14]. Nurjamuddin. (2012). Analisis Efesiensi Pengendalian Persediaan Bahan Baku Setengah Jadi Dengan Menggunakan Metode Eoq (Economic Order Quantity) Pada Pt.Utama Harmoni Sejahtera Di Samarinda. Ejournal Administrasi Bisnis , 5.

[15]. Pardede, P. M. (2005). Manajemen Operasi Dan Produksi . Jakarta: Andi Offset.

[16]. Rahmawan, A. (2016). Analisis Pengendalian Persediaan Bahan Pelumas Dan Bahan Kimia Untuk Menunjang Produksi Pada Pt.Meratus Jaya Iron Dan Steel Di Batulicin. Jurnal Ilmiah Ekonomi Bisnis, Vol 2, No 1, 143-150.

[17]. Rambung, A. L. (2017). Analisis Efesiensi Pengendalian Persediaan Bahan Setengah Jadi Dengan Metode Eoq (Economic Order Quality) Pada Pt Utama Harmoni Sejahtera Di Samarinda. Ejournal Administrasi Bisnis .

[18]. Rangkuti, F. (2004). Manajemen Persediaan Aplikasi Di Bidang Bisnis . Jakarta: Pt Grafindo Persada.

[19]. Sugiyono. (2015). Metode Penelitian . Bandung : Alfabeta.

[20]. Sugiyono. (2016). Metode Penelitian. Bandung: Alfabeta.

[21]. Suryono, D. (2013). Metodelogi Penelitian Kualitatif Dan Kuantitatif Dallam Bidang Kesehatan . Yogyakarta: Nuha Medika.

[22]. Taroleh, G. D. (2016). Analisis Persediaan Bahan Baku Di Rumah Makan Sabuah Oki-Manado. Jurnal Berkala Ilmiah Efesiensi, 1-10.

[23]. Trihudiyatmanto, M. (2017). Analisis Pengendalian Bahan Baku Dengan Menggunakan Metode Economic Order Quality (Eoq) (Studi Empiris Pada Cv Jaya Gemilang Wonosobo). Jurnal Ppkm Iii (2017) 220 - 234 Program Studi Manajemen Fakultas Ekonomi .

[24]. Usry, C. (2006). Akuntansi Biaya . Jakarta: Salemba Empat.

[25]. Wijaya, D. D. (2016). Analisis Pebngendalian Bahan Baku Ikan Pada Pt.Celebes Minapratama Bitung. Jurnal Emba, 578-591. 